\title{
Auditor Switching in the Economic Crisis: The Case in Greece
}

\author{
Ervin L. Black ${ }^{1}$, F. Greg Burton ${ }^{1}$, Anastasia G. Maggina ${ }^{2} *$ \\ ${ }^{I}$ Professor Of Accounting,Brigham Young University, USA \\ ${ }^{2}$ Business Consultant/Research Scientist, Greece \\ *Corresponding author E-mail:a.maggina@yahoo.com
}

\begin{abstract}
This study examines auditor switching using discriminant analysis and logistic regression. These two statistical techniques have been employed to show both whether auditor switching can be forecasted and which method better fits the data for companies listed on the Athens Stock Exchange. Using logistic analysis, auditor switching can be forecasted with prediction accuracy which exceeds 92.0 percent. In addition, we find that four financial ratios (Working Capital/Total Assets, Return on Assets, Market Value of Equity/Book Value of Total Debt, Sales/Total Assets) help explain the discrimination between companies that switch auditors and those that do not switch auditors.
\end{abstract}

Keywords: auditor switching,economic crisis,discriminant analysis,logistic regression,prediction accuracy.

\section{Introduction}

The economic crisis started during 2007 as a financial crisis, evolved into a fiscal crisis, then a monetary crisis, and progressed to a debt crisis. The financial crisis was triggered by a liquidity shortfall in the U.S. banking system. It resulted in the collapse of large financial institutions, the bailout of banks by national governments, and downturns in stock markets around the world. It contributed to the failure of key businesses and led to substantial financial commitments from governments (bailouts). In early 2010, fears of a sovereign debt crisis developed into the 2010 Euro Crisis causing significant financial difficulties particularly in Greece but affecting several other European Union members including Portugal, Ireland, Italy, Spain, and Belgium. The financial crisis led to the widening of bond yield spreads and risk insurance on credit default swaps between these countries and other EU members.

As the world economy suffered, governments and regulators looked for someone to blame for the crisis. Initial accusations were against the credit ratings agencies, bankers, and financial regulators, among others [17]. However, attention quickly turned to the role auditors played in the crisis. Critics eagerly pointed out that as a result of the financial crisis, the U.S. Government closed 22 banks that appeared healthy prior to the crisis. In addition, 28 distressed financial enterprises in U.K., U.S., Germany, Iceland, the Netherlands, France and Switzerland received unqualified audit opinions on their financial statements published immediately prior to the disclosure of financial difficulties. A report by the SEC noted that one of the banks, Bear Stearns, was highly leveraged, with a gross leverage ratio of approximately 33 to 1 prior to its collapse but auditors did nothing [17].

During July 2011, the U.S. Congress held a hearing on the role of the accounting profession in preventing another financial crisis, requiring testimony from accounting regulators, standard-setters and critics. In testimony during this hearing, former SEC Chief Accountant, Lynn Turner, emphasized that

"Auditors did not create the financial crisis, but they did have an extremely important role to play as gatekeepers to the capital markets in the U.S. and abroad. Gatekeepers including the auditors did play a role in the financial crisis. They failed to act on and provide information available to them to investors. This left investors much like the ship Titanic as it approached an unforeseen iceberg, without any red flags or warnings of the imminent dangers. In doing so, the auditors helped contribute to a crisis of confidence." [2]

At a meeting of the Investor Advisory Group in March 2012, a member of the group who also serves as the director of consumer protection at the Consumer Federation of America, said, "Auditors failed to perform their basic watchdog function in the financial crisis." Another member of the group noted, "While auditors did not cause the financial crisis, it is difficult to look at the list of failed Institutions that received an unqualified audit just months before they failed and 
conclude that auditors didn't play a role." [2]

While many constituents blamed auditors for not alerting the public to their clients' financial difficulties, company management is responsible for preparing accurate and complete financial statements. So the lack of communication about a company's financial stress is management's fault. Companies often change auditors when they are experiencing financial difficulties or are in conflict with auditors. So changing auditors may be a signal to the market that the company is having difficulties. The financial crisis provided the opportunity for troubled companies to change auditors and may have masked some of the reasons companies themselves switched auditors.

Auditor changes have been of interest to the profession and regulators because the motivation to change auditors may be related to a company's financial health. Auditor changes come from auditor resignations or dismissals by the company. Companies dismiss auditors for a number of reasons including changes in company control or management, audit fee reductions, accounting disagreements, and opinion shopping [20]. However, there are also strategic reasons for changing auditors. For instance, when a company goes through an initial public offering, hiring a Big Four auditor is a signal to the investing community that the company's financial statements have been carefully scrutinized and the financial statements are accurate. Therefore, not all auditor changes are attributable to a company's financial difficulties. Humphrey et al. [11] have stressed that the global financial crisis has been quite a fascinating one for the auditing profession. In Greece, for instance, the auditing profession has historically consisted of a state-controlled body of sworn-in accountants. Some liberalization has happened since 1992, but full liberalization has occurred only recently in response to the debt crisis. Auditing is no longer a government-dominated closed profession with restrictions on the amount of audit fees an auditor can charge. The abolishment of fee limits leads to higher audit fees. Higher audit fees are a concern for most companies and could be the catalyst for auditor switching, particularly during times of financial stress as Greek companies have experienced.

The purpose of this study is to highlight the particular characteristics of Greek companies that switch auditors versus companies that do not switch auditors as well as to determine the predictive ability of auditor switching using financial ratios as predictors. The recent liberalization of the Greek auditing profession provides a unique setting for studying auditor switching because auditors are competing for clients and not subject to fee restrictions. This study contributes to the literature as it investigates auditor switching behaviour in the specific circumstance of the economic crisis in Greece. The rest of the paper is organized as follows. The next section reviews the literature. Section III contains the research design. Section IV presents empirical findings. Section V concludes with a summary and suggestions for further future research.

\section{Literature Review}

A number of studies have addressed the question of why client firms switch auditors [18] , [12] , [9]). These studies have considered agency theory perspectives (board and management characteristics, growth, issuance of new stock or debt, etc.) as well as factors related to opinion-shopping, including changes prompted by a company's financial stress. The interest in auditor switching is partly triggered by regulatory concerns that auditor changes might compromise financial reporting (opinion shopping) and partly by the interest in how capital markets interpret auditor switching.

Motivating factors identified in prior research that explain why firms change auditors include changes in corporate management, the need for additional auditing services, disagreements over reporting matters, and conflict over audit fees [5] , [6] , [8]. An additional critical variable influencing auditor switching is financial distress [16]. A major finding indicates that there is a higher incidence of auditor switching among failing firms. Also, it has been hypothesized that firms demand higher-quality audits when they have long-term debt contracts [8]. The issuance of new securities plays a role in companies' perceptions. It either motivates the firm to change auditors or it operates as an indication of the nature of the change itself. An auditor change is argued to have signalling value regarding the firm and information about the firm vis-a-vis accounting data [19].

The different research designs used to study auditor switches has affected the consistency of these studies results and implications. For example, size did not have an effect on auditor switching among failing firms while it had an effect on more healthy companies [16]. Evidence shows that the increase in litigation against auditing firms does not correlate to substandard performance [13]. On the other hand, litigation risk makes auditors more selective in their choice of clients [15]. Litigation risk is approximated by factors that partially explain the auditor switching phenomenon. These include audit failure variables (i.e. auditors' independence, ratios of inventories and receivables to assets) and auditors' resignation variables (variability in stock returns), among others. Because the audit assignment is a bilateral issue, clients also play a role. Prior research indicates that clients change their auditors for a variety of reasons [9]. An audit client's characteristic constitutes a random variable which changes overtime.

Using publicly available data for the 186 experimental and 186 control clients, Williams [21]) developed and employed a theoretical model to explain auditor switches. The model, which uses the stewardship hypothesis as reflected in the agency theory literature, is first used to explain the demand for auditing. The same hypothesis is used to develop a theory of auditor choice and auditor change. The three concepts concerning the theory of auditor change representing 
the theoretical basis for selecting variables in a model explaining auditor changes are: 1) change in client contracting environment, 2) auditor effectiveness, and 3) client reputation. These concepts are developed as variables in the model using the following measures:

- client replaces either the president, chief executive officer, chief financial officer or treasurer,

- percentage change in common stock,

- percentage change in sales,

- auditor's percentage of industry market share,

- longevity in the audit engagement,

- client received negative media publicity,

- client received a first-year qualified audit opinion,

- client changed accounting principles,

- percentage change in return on assets, and

- percentage change in earnings per share.

Williams [21] developed and used operational variables to empirically test the proposed relationships. The common significant variables relating to an auditor change were audit fees and qualified audit opinions. Additional audit services and client/auditor relationships also appeared to be significant. His findings support the contention that firms do not change auditors in an effort to find a lenient auditor. The main reasons that make firms to change auditors are their dissatisfaction with the quality of the predecessor audit firm or their perception that the successor firm can create audit efficiencies. Another reason for the change may be a firm's willingness to improve its monitoring system. The evidence drawn from this study refutes the criticisms of the auditing profession that clients seek auditor changes for manipulative purposes. William's [21]) model correctly classified $66.1 \%$ of the clients in the sample of 186 matched-pair firms.

Teoh [18] found that investors' reaction to auditor switches depends on the context of the switch and the characteristics of the switching firm. The audit opinion prior to the switch provides information that plays an important role. The preswitch audit opinion determines the stock price response to the announcement of an auditor's change. The stock price reaction to a switch will tend to be more negative after a clean opinion rather than after a qualified opinion because high value retentions are more common after a clean opinion while low value retentions are more common after a qualified opinion. In contrast, other studies have shown that the market reacts negatively to auditor switches because the switch signals that the firm was attempting to influence the auditor. A switch after a clean opinion leads to a positive probability of qualification. It implies a rise in the cost to the firm if it is qualified that leads to a greater stock price decline at the announcement of a switch after a clean opinion.

On the other hand, the status of the firm's value may lead to auditor switching. A firm with intermediate value switches auditors in the hope of obtaining a favourable opinion. Firms with a low value do not instigate a switch because there is virtually no hope of improving its position. A high value firm abstains because it is confident of a clean opinion from the incumbent auditor.

Krishnan [12] using an initial sample for the years 1986, 1987, and 1988, focused his study on the auditor's opinion formulation process to switching and non-switching clients in the year prior to the switch. The switching rate is 6.6 percent. He investigated the possibility that auditor switches are not caused by the receipt of qualified opinions, but by auditor's use of conservative judgments for some clients. While conservatism refers to a number of accounting and auditing issues, the overall conservatism of the auditor is assumed to be reflected in a tendency to issue qualified opinions. He used a probit model of the qualification decision to estimate with different threshold values for prospective switchers and non-switchers measuring different judgments applied to the two groups of clients. The results provide credence to the hypothesis that threshold values for switchers are significantly lower and potentially more conservative than those for non-switchers [12]. The author finally argued that the evidence indicating that opinions do not improve after switches suggests that "opinion shopping" is generally futile. Furthermore, the decision to choose or switch auditors in a subsidiary company often occurs at the parent level and is determined by group characteristics of the subsidiary. Branson et al. [3] asserted that apart from the traditional research on auditor choice and auditor switching "'referral" the situation where the subsidiary-encouraged by the parent company-appoints the same auditor as the parent company,must be considered as an explanatory variable to understand auditor switching behaviour in small open economies like Belgium.

Chan et al. [4] examined how particular institutional characteristics of heavy government influence on company management and audit firms in China affect auditor opinions. Specifically, they studied whether local auditors who have greater economic dependence on local clients are more likely to report favourably on their local-government clients. Listed companies in China are owned primarily by local governments, and the majority of local audit firms had close connections with these governments. Hodgdon et al. [10] examined the impact of auditor choice on IFRS compliance and their results suggest that compliance is positively related to auditor choice using as explanatory variables the size, profitability, leverage, degree of international diversification, and whether a firm has a U.S. listing or was audited according to International Standards of Auditing. Auditor choice is defined as being audited by a Big $5+2$ auditor (the international Big 5 firms plus BDO and Grant Thornton). 
Sikka [17] has argued that the fact that many financial enterprises have sought state support within a short period of receiving unqualified audit opinion and auditors have collected large amounts in audit and non-audit fees have raised questions about the value of company audits, auditor independence and quality of audit work, economic incentives for good audits and the knowledge base of auditors.

\section{Research Design}

\subsection{Research Method}

Our research questions are:

$R Q 1$ : Can Greek companies that switch auditors be distinguished from Greek companies that do not switch auditors?

$R Q 2$ : Can a model be developed that correctly classifies switching and non-switching companies?

$R Q 3:$ Can company data be used for prediction useful in decision making?

We use discriminant analysis and logistic regression to compare companies that switch auditors with a control group of non-switching companies [14]. We use both methods in this study as they give somewhat different insights into the research issue.

Discriminant analysis uses explanatory or predictor variables to classify items into their correct populations. The method produces a discriminant function that is a linear combination of the explanatory variables. We include the four financial ratios used in the pioneering work of Altman [1]) as predictors. These ratios are 1) Working Capital/Total Assets (a measure of the net liquid assets of the firm relative to the total capitalization where liquidity and assets characteristics are explicitly considered); 2) Return on Assets (a measure of the productivity of the firm's assets); 3) Market Value of Equity/Book Value of Total Debt (a measure which shows how much the firm's assets can decline in value before the liabilities exceed the assets); and 4) Sales/Total Assets (a measure of management's capability in dealing with competitive conditions).

Logistic regression is a second but closely related method to discriminant analysis. In our study, it uses explanatory variables to estimate the probability that a firm is drawn from a given population (firms that switch auditors or do not switch auditors). The classified items are firms in our case and the two populations of interest are firms that switch auditors and those that do not. Sample data are used to estimate a linear function that maximizes the probability of a correct classification of a firm. The explanatory variables in our study, denoted later by vector $\mathrm{x}=\left(\mathrm{x}_{1}, \mathrm{x}_{2}, \mathrm{x}_{3}, \mathrm{x}_{4}\right)$, where $\mathrm{x}_{1}=$ Working Capital/Total Assets,

$\mathrm{x}_{2}=$ Return on Assets,

$\mathrm{x}_{3}=$ Market Value of Equity/Book Value of Total Debt, and

$\mathrm{x}_{4}=$ Sales/Total Assets, respectively.

Whether a firm switches auditors or not is denoted by indicator variable $y$ where $y=1$ if the firm switches auditors and $\mathrm{y}=0$ otherwise.

The discriminant analysis model assumes that a firm's explanatory vector $\mathrm{x}$ is drawn from one of two multivariate normal distributions corresponding to firms with $\mathrm{y}=1$ and $\mathrm{y}=0$, respectively. To examine our research questions we postulate that the two populations have different means but the same covariance matrix. A linear discriminant function, $\mathrm{w}=\mathrm{b}_{0}+\mathrm{b}_{1} \mathrm{x}_{1}+\mathrm{b}_{2} \mathrm{x}_{2}+\mathrm{b}_{3} \mathrm{x}_{3}+\mathrm{b}_{4} \mathrm{x}_{4}$, is estimated from the sample data. Here $\mathrm{w}$ denotes the discriminant value, $\mathrm{b}_{0}$ is an intercept coefficient, and $b_{1}$ through $b_{4}$ are estimated discriminant coefficients for the four explanatory variables. Because $x$ is assumed to be multivariate normal, the linear discriminant values $\mathrm{w}$ for firms drawn from the same population are random outcomes from a normal distribution. Under the research hypothesis, the normal distributions for $\mathrm{w}$ corresponding to the two populations $y=1$ and $y=0$ have different means but a common variance. The coefficients of the discriminant function are estimated in such a way that the statistical separation of the $y=1$ and $y=0$ samples on the linear discriminant scale is as large as possible. These results are discussed in the next section.

Logistic regression considers the probability $\operatorname{Pr}(\mathrm{y}=1 \mid \mathrm{x})$ that a firm with explanatory vector $\mathrm{x}$ will switch auditors $(\mathrm{y}=1)$. For brevity, we let $\mathrm{p}=\operatorname{Pr}(\mathrm{y}=1 \mid \mathrm{x})$. By definition, the probability that the firm will not switch auditors is $1-\mathrm{p}=\operatorname{Pr}(\mathrm{y}=0 \mid \mathrm{x})$. The logistic regression model assumes that the probability of event $\mathrm{y}=1$ is a linear combination of the explanatory variables as $\log [\mathrm{p} /(1-\mathrm{p})]=\mathrm{c}_{0}+\mathrm{c}_{1} \mathrm{x}_{1}+\mathrm{c}_{2} \mathrm{x}_{2}+\mathrm{c}_{3} \mathrm{x}_{3}+\mathrm{c}_{4} \mathrm{x}_{4}$, where

$\mathrm{p} /(1-\mathrm{p})$ denotes the odds in favour of event $\mathrm{y}=1$,

$\mathrm{c}_{0}$ is an intercept term, and

$c_{1}$ through $c_{4}$ are logistic regression coefficients that are estimated from the sample data using the method of maximum likelihood.

The log-odds value in the logistic regression function is often referred to as the "logit" value. The model estimation attempts to associate large probabilities $\mathrm{p}$ with firms for which $\mathrm{y}=1$ and small probabilities $\mathrm{p}$ with firms for which $\mathrm{y}=0$. Results are discussed in the next section on Empirical Findings. 


\subsection{Sample Selection}

We selected companies listed on the Athens Stock Exchange (ASE) for investigation in this study. We do not partition the sample into resignations and dismissals as we are concerned more with the effects of financial stress on switching. The size of the sample is based on the number of firms recorded in the ASE website on 2009 which is two years after the start of the economic crisis. We used auditors' reports and financial statements for two years (2008 and 2009$)$ in order to identify auditor changes.

The total number of firms listed on the ASE in 2009 is 272 and 23 companies (8.46 percent) switched auditors during the year. The companies that changed auditors are from many industries. The final sample consists of 268 companies, of which 22 switched auditors. These are the companies that have financial statement data and audit reports for two consecutive years. In the final sample, 7.46 percent of companies switched auditors.

During the financial crisis time period we examine in this study, 2008-2009, only 4 of the 22 auditor changes moved to Big 4 auditing firms; 15 companies moved from one local firm to another local firm and the remaining 3 moved from one Big 4 auditing firm to another Big 4 auditing firm. During the period 2007-2008, 11 of 16 companies moved from one local auditing firm to another local auditing firm and only one company moved from a local auditing firm to a Big 4 auditing firm. In contrast, for the time period 1996-1997, five of the eleven companies that switched firms changed to Big Six auditors from the Governmental Sworn-in Auditors. The remaining six companies that switched auditors changed to newly establish private auditing firms.

\section{Empirical Findings}

Examination of the means of the variables used in the analysis reveal differences between companies that switched auditors and those that kept the same auditors. The largest difference between the two groups in both the one year and two year data is in the Equity/Total Debt (EQTD) ratio. The differences in all the ratios become smaller when outliers are excluded.

\begin{tabular}{|c|c|c|c|c|}
\hline & \multicolumn{2}{|l|}{ All Data } & \multicolumn{2}{|c|}{ Outliers Excluded } \\
\hline & ASW & NON ASW & ASW & NON ASW \\
\hline \multicolumn{5}{|c|}{ Panel B: One Year Before } \\
\hline WCTA & 0.0868 & -0.0136 & 0.0868 & 0.1192 \\
\hline NITA & -0.0113 & 0.0016 & -0.0113 & 0.0016 \\
\hline EQTD & 1.0868 & 4.0873 & 1.0868 & 2.0595 \\
\hline SATA & 0.5631 & 0.6820 & 0.5631 & 0.6820 \\
\hline \multicolumn{5}{|c|}{ Panel A: Two Years Before (one and two) } \\
\hline WCTA & 0.1009 & 0.0745 & 0.1009 & 0.1409 \\
\hline NITA & -0.0299 & -0.0080 & -0.0299 & -0.0060 \\
\hline EQTD & 0.9869 & 3.8383 & 0.9869 & 1.3398 \\
\hline SATA & 0.5719 & 0.7448 & 0.5719 & 0.7448 \\
\hline
\end{tabular}

Our sample data contain thirteen outliers in variable EQTD when using data for two years and 5 outliers in the data for one year. The ratio Working Capital/Total Assets (WCTA ) has only one outlier in the data for one year before the switch. In our research we seek to find the best fitting model by examining the empirical findings from tests of both discriminant analysis and logistic regression. In each year, a company is observed in one of two alternative states. Coefficients for each model and for each variable in one and two years before the event along with the whole data set are given below.

Wilks' Lamda is used to test the significance of the discriminant function as a whole. The significant lamda shown in Table 2 indicates that the null (that the two groups have the same mean discriminant function scores) can be rejected and we conclude that the model is discriminating. In discriminant analysis almost all variables contribute to the discrimination process (see Table 2) and in particular almost all variables contribute positively. Using all data either with one or two years before, only WCTA (Working Capital/Total Assets) has a negative predicted sign. When outliers are excluded all variables have a positive value. In contrast, in the logit almost all variables have a negative predicted sign except WCTA (Working Capital/Total Assets) which mainly has a positive predicted sign.

Once the values of the discriminant coefficients are estimated, it is possible to calculate discriminant scores for each observation in the sample, or any firm, and to assign the observations to one of the groups based on this score. The 
essence of the procedure is to compare the profile of an individual firm with that of the alternative groupings. In this manner, the firm is assigned to the group it most closely resembles.

Table 2: Regression Coefficients

\begin{tabular}{|c|c|c|c|c|c|c|c|}
\hline & \multicolumn{3}{|c|}{ ALL DATA } & \multicolumn{4}{|c|}{ OUTLIERS EXCLUDED } \\
\hline \multirow{2}{*}{\multicolumn{2}{|c|}{$\begin{array}{c}\text { DISCRIMINANT } \\
\text { Predicted Sign Coefficients }\end{array}$}} & \multicolumn{2}{|r|}{ LOGIT } & \multicolumn{2}{|c|}{ DISCRIMINANT } & \multicolumn{2}{|c|}{ LOGIT } \\
\hline & & Predicted & Sign Coefficients & Predicted $S$ & Sign Coefficients & s Predict & n Coefficients \\
\hline \multicolumn{8}{|c|}{ Panel A: One Year Before } \\
\hline WCTA & 0.266 & + & $0.072(0.797)$ & + & 0.150 & - & $0.006(0.991)$ \\
\hline NITA & 0.239 & - & $0.324(0.853)$ & + & 0.395 & - & $0.406(0.817)$ \\
\hline EQTD & 0.822 & - & $0.053(0.558)$ & + & 0.626 & - & $0.045(0.652)$ \\
\hline SATA & 0.518 & - & $0.214(0.590)$ & + & 0.645 & - & $0.204(0.605)$ \\
\hline \multicolumn{4}{|c|}{ Eigenvalue $=0.004$} & \multicolumn{4}{|c|}{ Eigenvalue $=0.002$} \\
\hline \multirow{2}{*}{\multicolumn{2}{|c|}{$\begin{array}{l}\text { Correlation }=0.061 \\
\text { Wilk's Lamda }=0.996\end{array}$}} & \multirow{2}{*}{\multicolumn{2}{|c|}{$\begin{array}{c}X^{2}=1.842 \\
\text { Significance }=0.765\end{array}$}} & \multicolumn{4}{|c|}{ Correlation $=0.048 \quad X^{2}=0.958$} \\
\hline & & & & Wilk’s lar & $\mathrm{amda}=0.998$ & Signif. $=$ & \\
\hline \multicolumn{2}{|r|}{$X^{2}=0.993$} & \multicolumn{2}{|c|}{ Wald test $=117.315$} & \multicolumn{2}{|c|}{$x^{2}=0.605$} & \multicolumn{2}{|c|}{ Wald test $=114.831$} \\
\hline \multicolumn{2}{|r|}{ Significance $=0.911$} & & & \multicolumn{2}{|c|}{ Significance $=0.962$} & & \\
\hline & N(Total) 535 & & & \multirow{2}{*}{\multicolumn{2}{|c|}{ N(Total) 535}} & & \\
\hline \multicolumn{2}{|r|}{ N(Valid) 268} & & & & & & \\
\hline
\end{tabular}

Panel B: Two Years Before (one and two)

DISCRIMINANT LOGIT

DISCRIMINANT

Predicted Sign Coefficients Predicted Sign Coefficients Predicted Sign Coefficents Predicted Sign Coefficients

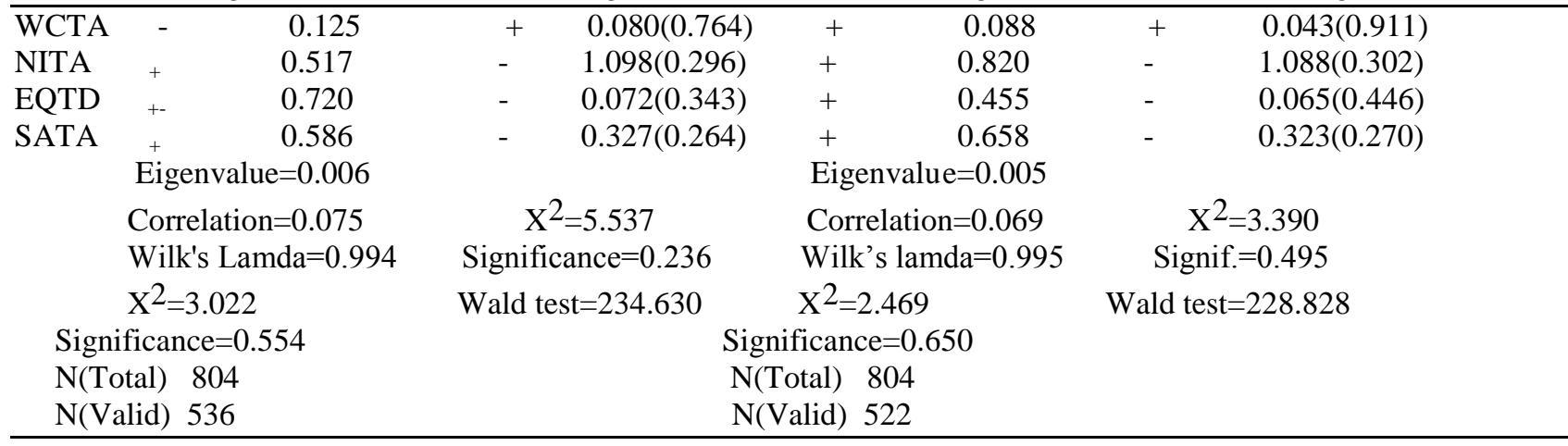

\section{(p-values are given in parenthesis)}

As far as the correct classification, results shown in Table 3 justify the preference of logistic regression compared to discriminant analysis. Logistic regression performs better in this analysis because discriminant analysis has some constraints on the data (must follow a normal distribution). When all data (both years) are used the percentage of correct classification is 92.5 percent with a logit model and only 45.0 percent with discriminant analysis. When outliers are excluded the rates are 92.3 percent and 44.7 percent, respectively. In a similar vein, when one year-before data are used results are 92.5 percent for logit and 32.8 percent for discriminant analysis. When outliers are excluded the rates are 92.4 percent and 41.6 percent, respectively. The logit rates are similar to a prior study [14] where auditor switching was investigated with data in the decade of 1990's with five financial ratios as predictors (Working Capital/Total Assets, Retained Earnings/Total Assets, Return on Assets, Equity/Total Debt, Sales/Total Assets). Compared with other international studies (Williams [21]) the prediction accuracy in this study is much higher.

When assets size is included in the models, the picture changes and the prediction accuracy is reduced to 40.5 percent when discriminant analysis is employed. When data for two years before are used the rate of correct classification reduced to 40.5 percent (from 48.7 percent to 44.8 percent with outliers excluded). When data for one year before the switch is used the rate decreases from 32.8 percent to 32.5 percent (decreases from 41.6 percent to 35.9 percent when outliers are excluded). When logit is employed, using assets as a test variable with one year data the correct classification remains the same ( 92.5 percent) and 92.4 percent with outliers excluded, and with two years data the rate remains the same ( 92.5 percent) and 92.3 percent with outliers excluded. 
Table 3:Classification Table for GROUP (Percent Correct-Overall Index)

\begin{tabular}{|c|c|c|c|c|}
\hline & \multicolumn{2}{|c|}{ Discriminant Analysis } & \multicolumn{2}{|l|}{ Logit } \\
\hline One-Year-Before (All data) & $\begin{array}{l}76(30.6) \\
8(40.0) \\
32.8 \%\end{array}$ & $\begin{array}{l}172(69.4) \\
12(60.0)\end{array}$ & $\begin{array}{l}248 \\
20 \\
92.5 \%\end{array}$ & $\begin{array}{l}0(100.0) \\
0(0.0)\end{array}$ \\
\hline One-Year-Before (Outliers excluded) & $\begin{array}{l}98(40.5) \\
9(45.0) \\
41.6 \%\end{array}$ & $\begin{array}{l}144(59.5) \\
11(55.0)\end{array}$ & $\begin{array}{l}242 \\
20 \\
92.4 \%\end{array}$ & $\begin{array}{l}0(100.0) \\
0(0.0)\end{array}$ \\
\hline Two Years-Before(All data) & $\begin{array}{l}218(44.0) \\
9(45.0) \\
45.0 \%\end{array}$ & $\begin{array}{l}278(56.0) \\
23(57.5)\end{array}$ & $\begin{array}{l}496 \\
40 \\
92.5 \%\end{array}$ & $\begin{array}{l}0(100.0) \\
0(0.0)\end{array}$ \\
\hline $\begin{array}{l}\text { TwoYears-Before } \\
\text { (Outliers excluded) }\end{array}$ & $\begin{array}{l}232(48.1) \\
18(45.0) \\
48.7 \%\end{array}$ & $\begin{array}{l}250(51.9) \\
22(55.0)\end{array}$ & $\begin{array}{l}482 \\
40 \\
92.3 \%\end{array}$ & $\begin{array}{l}0(100.0) \\
0(0.0)\end{array}$ \\
\hline
\end{tabular}

Based on the above empirical findings, our results provide evidence that the prediction accuracy is very high compared to rates in other business events like prediction of bankruptcies, corporate acquisitions, audit reports, etc.

\section{Conclusions and Suggestions for Further Future Research}

Company failures and financial difficulties from the financial crisis have eroded confidence in auditors and caused financial statement users to doubt auditor assurances. The financial crisis has called into question the usefulness of auditors' reports. In such a framework auditor switching has been a challenge for further investigation. The question that has been raised is about the intensity of the phenomenon of auditor switching and how it can be approached effectively. It has been widely argued that the current financial crisis is an opportunity to consider alternative institutional arrangements for auditing.

Application of two analytical techniques (discriminant analysis and logistic regression) is shown to be a useful mechanism to forecast auditor switching using some financial ratios as predictors. Four financial ratios (Working Capital/Total Assets, Return on Assets, Market Value of Equity/Book Value of Total Debt, Sales/Total Assets) are very good predictors since prediction accuracy amounts to 92.5 percent using logistic regression, which is much higher than in other international studies and also similar to the results of a prior relevant study with data in the decade of 1990s. We note that size as measured by total assets does not play a role in the prediction accuracy. Future research could examine other financial statement data/ratios to determine their usefulness in understanding auditor switching as well as examine other settings in distressed and non-distressed economies.

This study is limited to listed (publicly-traded) companies in Greece. How the situation would be formed in case of privately held companies is another venue for research. Auditor switching in conjunction with the operation of audit committees could be another opportunity for research since audit committee formation is growing as a new institution in the business arena in Greece but it is still valid in a small number of companies. Note that the vast majority of the companies included in the sample of this study have no Audit Committee. This is important in light of the European Commission's consideration of a restructuring of the audit industry that requires mandatory rotation and/or caps on advisory fees as well as prohibiting auditors from supplying certain non-auditing services [7].

\section{References}

[1] Altman, E.I. ,Financial Ratios, Discriminant Analysis and the Prediction of Corporate Bankruptcy The Journal of Finance (1968) 589-609

[2] Auditors Asked to Do More for Financial Stability, Accounting Today for the WEB CPA (2012) March

[3] Branson, J. and D. Breesch, Referral as a Determining Factor for Changing Auditors in the Belgian Auditing Market: An Empirical Study. International Journal of Accounting, 39 (2004) 307-326

[4] Chan, K.H., K.Z. Lin ,P.L.Mo , A Politico-Economic Analysis of Auditor Reporting and Auditor Switches. Review of Accounting Studies 11(2006) 21-48

[5] Chow, C.W. and S.J. Rice, Qualified Audit Opinions and Auditor Switching The Accounting Review (1982) $326-335$

[6] DeAngelo, L. , Mandated Successful Efforts and Auditor Choice Journal of Accounting and Economics (1982) 171-203

[7] European Parliament Committee Votes for Audit Firm Rotation,Accounting Today for the WEB CPA,(2013) April

[8] Eishenseher, J.W. , D.Shields , The Correlates of CPA-firms Change for Publicly Held Corporations Auditing: A Journal of Practice and Theory (1983) 23-37

[9] Gigler, F. , M. Penno , Imperfect Competition in Audit Markets and its Effect on the Demand for Audit-Related Services The Accounting Review (1995) 317-336 
[10] Hodgdon, C., R. H. Tondkar, A. Adhikari , D. W. Harless, Compliance with International Financial Reporting Standards and Auditor Choice: New Evidence on the Importance of Statutory Audits The International Journal of Accounting 44 (2009) 33-55

[11] Humphrey, C., A. Kausar, A. Loft , M.Woods, Regulating Audit beyond the Crisis: A Critical Discussion of the EU Green Paper European Accounting Review 20 (2011) 431-457

[12] Krishnan, J. , Auditor Switching and Conservatism The Accounting Review 60 (1994) 200-215

[13] J. Krishnan, Litigation Risk and Auditor Resignations The Accounting Review 72 (1997) 539-561

[14] Maggina, A., Auditors' Switching: An Empirical Investigation Global Journal of Business Research 2 (2008) 85-100

[15] Pratt, J. ,J. D. Stice , The Effects of Client Characteristics in Auditor Litigation Risk Judgments, Required Audit Evidence and Recommended Audit Fees The Accounting Review (1994) 639-656

[16] Schwartz, K. B. , E. R. Menon, Auditor Switches by Failing Firms The Accounting Review 60 (1988) 248-261

[17] Sikka, P. , Financial Crisis and the Silence of Auditors Accounting, Organizations and Society 34 (2009) 868-873

[18] Teoh, S. H. , Auditor Independence, Dismissal Threats, and the Market Reaction to Auditor Switches Journal of Accounting Research 30 (1992) $1-23$

[19] Titman,S.,B.Trueman , Information Quality and Valuation of New Issues Journal of Accounting and Economics 8 (1986) 159-172

[20] Turner, L.E., J.P. Williams, T.R. Weirich, An Inside Look at Auditor Changes The CPA Journal. Vol. LXXV (2005)

[21] Williams, D. D. , The Potential Determinants of Auditor Change Journal of Business, Finance and Accounting 15 (1988) $243-262$

\section{Exhibit 1}

Auditing firms in Greece include the following: PRICEWATERSHOUSE COOPERS

KPMG

ERNST \& YOUNG

DELOITTE

GRANT THORNTON

BDO

SOL

ABACUS

BAKER TILLY

FRS GLOBAL

H.B.P.

MONDAY PAPAKIRIAKOY

MOORE STEVENS

RKF EUROAUDITING

PRIME AUDIT

Q.A.S.

RADIOUS PROFESSIONAL SERVICES

R.M.S. STILLIANOU

AXON

HELLENIC AUDITING

ALTERNATIVE AUDITING

ORION AUDITORS

NEXIA EUROSTATUS

SIGALAS AUDITORS

ACES AUDITORS

METRON AUDITING

DNP AUDIT

DELTA AUDITORS

KYPRIS AND ASSOCIATES 